\title{
Physicochemical and functional properties of cassava flour grown in different locations in Sabah, Malaysia
}

\author{
${ }^{1}$ Hasmadi, M., ${ }^{1}$ Harlina, L., ${ }^{1}$ Jau-Shya, L., ${ }^{1}$ Mansoor, A.H., ${ }^{1}$ Jahurul, M.H.A. and \\ ${ }^{2}$ Zainol, M.K. \\ ${ }^{1}$ Food Technology and Bioprocessing Program, Faculty of Food Science and Nutrition, Universiti Malaysia \\ Sabah, 88400 Kota Kinabalu, Sabah \\ ${ }^{2}$ School of Food Science and Technology, Universiti Malaysia Terengganu, 21030 Kuala Terengganu, \\ Terengganu, Malaysia
}

\begin{abstract}
Article history:
Received: 11 December 2019 Received in revised form: 12 February 2020

Accepted: 14 February 2020 Available Online: 9 March 2020
\end{abstract}

\section{Keywords:}

Cassava,

Flour,

Proximate analysis,

Functional properties,

Thermal properties

\section{DOI:}

https://doi.org/10.26656/fr.2017.4(4).405

\begin{abstract}
The tuber of cassava is used as raw materials in the bakery, food, pharmaceutical and garment industries. The nutritional value of cassava roots is important because they are the main part of the plant consumed in developing countries. However, there is much variation in the nutrient quality of the cassava root depends on the several factors, such as geographic location, variety, age of the plant, and environmental conditions. This study was performed to compare and provide information on physicochemical and functional properties of cassava flour planted in two different districts in Sabah, Malaysia, namely Tawau and Semporna. Proximate analysis showed significant differences $(\mathrm{p}<0.05)$ in crude protein $(2.07$ and $2.69 \%)$, crude fat $(0.55$ and $0.68 \%)$ and dietary fibre contents (2.38 and $2.09 \%)$. Determinations on physicochemical and functional characteristics of the cassava flour showed significant differences $(\mathrm{p}<0.05)$ in bulk density $(0.57$ and $0.79 \mathrm{~g} /$ $\left.\mathrm{cm}^{3}\right), \mathrm{pH}$ (6.75 and 6.72), colour and foam capacity (3.66 and 7.33\%) while there was no significant difference shown in water and oil absorption capacities as well as emulsion capacity. Cassava planted in Semporna was observed to have high values of all pasting property parameters relative to the one planted in Tawau except for the setback viscosity. Gelatinization properties of flours showed significant differences $(\mathrm{p}<0.05)$ in onset $(70.59$ and $\left.68.99^{\circ} \mathrm{C}\right)$ and end temperatures $\left(79.81\right.$ and $\left.80.03^{\circ} \mathrm{C}\right)$.
\end{abstract}

\section{Introduction}

Cassava or tapioca also called 'ubi kayu' in local Malay is a tropical root or tuber crop under family of Euphorbiaceae. The cassava (Manihot esculenta Crantz) is cultivated mainly in the tropic and sub-tropic regions of the world, over a wide range of environmental and soil conditions (Chávez et al., 2005). It is tolerant of insect pests and diseases and is very tolerant of drought and heat stress. Cassava is a perennial, subtropical, woody shrub, grown as annual and is valued for its underground starchy tubers (roots). Cassava is an important source of energy as the staple food for more than 500 million people in Africa, Latin America and Asia. Cassava is a mesophyte and can be grown in the fallow high land, hill slope, rice field and other unutilized high lands. It can be grown in poor soils and produce fairly good yield where other crops almost fail and provide food security (Siritunga et al., 2004).

The cassava is not a labour-intensive crop and produces well on marginal soils. In many of the cassava growing regions of the world, however, the cassava does not achieve its yield potential, due primarily to disease and limited inputs such as fertiliser and irrigation (Siritunga and Sayre, 2004). Estimates of the Food and Agriculture Organisation of the United Nations (FAOSTAT, 2011) put world production of cassava at more than 230 million metric tonnes annually. Major producers of cassava include Nigeria (37.5 million tonnes per annum), Brazil (24.5 million tonnes) and Thailand (22.0 million tonnes). Malaysia Department of Agriculture recorded about 2,385 hectares cassava grown in Malaysia in 2018 producing about 34,996 metric tonnes valued at more than RM31 million. Estimated area of cassava planting area in Sabah for the year 2018 about 444 hectares with a potential yield of 3,750 metric tonnes (Jabatan Pertanian Malaysia, 2019).

In Malaysia, two types of cassava have been introduced to farmers and also to the small and medium- 
sized industry. Several varieties are grown in Malaysia which are Sri Pontian, white, yellow, Medan, SM156219, black twig, Perintis and MM92, to name a few. The 'bitter' type such as Sri Kanji 1 and Sri Kanji 2 are varieties with high cyanide content, but they have high starch contents and are thus used in starch processing. The 'sweet' or edible varieties are mainly used for food and food products. The edible varieties such as Medan and Sri Pontian are used to make traditional Malay and Nyonya cakes and snacks such as bingka, kerepek, keropok and opak (Tan and Engku Ismail, 2010). None of the previous studies examined cassava grown in Sabah, particularly in the district of Tawau and Semporna.

The cassava is an important component in the diets of more than 800 million people around the world (FAO, 2007) and is the third-largest carbohydrate food source within the tropical regions, after rice and corn (Ceballos et al., 2004; Ceballos et al., 2006). Cassava is referred to as a food security crop (Barratt et al., 2006), which can be left in the ground for extended periods of up to two years until required. It is used mainly as a fresh food item but is also processed into various food and non-food products, such as starch, flour, beverages, animal feeds, biofuels and textiles (Grace, 1977; Tewe and Lutaladio, 2004).

In the tropical regions, cassava is the most important root crop and, as a source of energy, the calorific value of cassava is high, compared to most starchy crops (Okigbo, 1980). The protein content is extremely low, however, and ranges between 1-3\% (Buitrago, 1990; Salcedo et al., 2010). The cassava root contains a number of mineral elements, in appreciable amounts, that are useful in the human diet. The root contains significant amounts of iron, phosphorus and calcium, and is relatively rich in vitamin C (Enidiok et al., 2008).

The nutritional value of cassava roots is important because they are the main part of the plant consumed in developing countries. However, there is much variation in the nutrient quality of the cassava root depends on the several factors, such as geographic location, variety, age of the plant, and environmental conditions (Benesi et al., 2007; Sanni et al., 2008; Montagnac et al., 2009). From the literature search, we found that no research has been reported and discussed associated with the proposed study. Most of the research related conducted in other regions especially Africa and other parts of tropical countries.

To the best of our knowledge, there is scanty of information on chemical, functional and pasting properties for locally grown cassava. Such data can benefit the food industry where it could be used in food formulations as well as improving the functionality of cassava starch when used as a supplement ingredient in food production or to be used as biopolymer components in edible film preparations. It was necessary to determine the nutrient composition of cassava obtained in Sabah and to study its physicochemical and functional characteristics of cassava flour.

\section{Materials and methods}

\subsection{Raw materials}

Matured cassava (9 months of age) was collected from Tawau and Semporna, Sabah, Malaysia was harvested in February to March 2017.

\subsection{Flour preparation}

The method used as described by Bankole et al. (2013) with several modifications. The drying process was conducted at $65^{\circ} \mathrm{C}$ for $48 \mathrm{hrs}$. Dried cassava chips were then ground and sieved using $500 \mu \mathrm{m}$ sieve then stored for further analysis.

\subsection{Proximate analysis}

Total moisture content, total ash, crude lipid, crude protein, total dietary fibre and total carbohydrates were determined using AOAC (2000) (Method 952.10, 900.02, 934.01, 991.43, 960.52).

\subsection{Bulk density}

Bulk density of the flours was determined according to the method of Danbaba et al. (2014) with modifications. The sample $(100.00 \pm 0.05 \mathrm{~g})$ was weighed and gently filled in $250 \mathrm{~mL}$ graduated cylinder. The bottom of the cylinder was gently tapped ten times until there was no further diminution of the sample level. Bulk density was expressed as the weight of sample per unit volume of sample $(\mathrm{g} / \mathrm{mL})$. Measurements were made in triplicate.

\subsection{Colour}

The colour of cassava flour was determined using Hunter Colour Meter based on the method described by Siddiq et al. (2010). Results were expressed in the CIE $L^{*} a^{*} b *$ colour space.

\section{$2.6 \mathrm{pH}$}

The $\mathrm{pH}$ of the cassava flour was determined using pH-meter based on the method described by Eriksson (2013).

\subsection{Water absorption capacity}

Water absorption capacity was determined using the method described by Mustapha et al. (2015). Distilled 
water $(40 \mathrm{~mL})$ was added to $2.00 \pm 0.05 \mathrm{~g}$ of cassava flour in a pre-weighed centrifuge tube. The dispersions were stirred occasionally, held for 30 mins, followed by centrifugation for $15 \mathrm{mins}$ at $1000 \times \mathrm{g}$. The supernatant was decanted, excess moisture was removed by draining for $24 \mathrm{hrs}$ at $50^{\circ} \mathrm{C}$, and the sample was reweighed. The amount of water bound by the flour was determined by difference and expressed as weight of water bound by dry flour $(100 \mathrm{~g})$.

\subsection{Foaming capacity}

The method used to determine foam capacity of samples is as described by Mustapha et al. (2015) with several modifications. During the homogenization process, the speed used was $160 \mathrm{rpm}$ for 10 mins. Foam capacity of samples then calculated by using the formula as follow:

$$
\text { Foam capacity }(\%)=(\mathrm{B}-\mathrm{A}) / \mathrm{A} \times 100
$$

Where $\mathrm{A}=$ volume before homogenization $(\mathrm{mL}), \mathrm{B}=$ volume after homogenization $(\mathrm{mL})$.

\subsection{Emulsion capacity}

The method used to determine the emulsion capacity of samples is as described by Mustapha et al. (2015) with slight modifications. Samples $(1.00 \pm 0.05 \mathrm{~g})$ were mixed with $10 \mathrm{~mL}$ of vegetable oil in pre-weighed centrifuge tubes. The contents were stirred for $1 \mathrm{~min}$ with thin brass wire to disperse the sample in the oil. After a holding period of $30 \mathrm{mins}$, the tubes were centrifuged for $20 \mathrm{mins}$ at $3000 \times \mathrm{g}$ at room temperature $\left(27^{\circ} \mathrm{C}\right)$. The oil absorption capacity was expressed as grams of oil bound per gram of the sample on a dry basis.

\subsection{Pasting properties}

The pasting properties of samples were determined by using Rapid Visco Analyzer (RVA) as describe by Chandanasree et al. (2016). Several parameters recorded which included peak viscosity (PV), trough viscosity (TV), breakdown viscosity (BV), final viscosity (FV), setback viscosity $(\mathrm{SV})$, pasting temperature $(\mathrm{Pt})$ and peak time (PT).

\subsection{Gelatinization properties}

Gelatinization properties of samples were determined by using Differential Scanning Calorimeter (DSC) based on the method described by Chandanasree et al. (2016). Several parameters such as onset temperature $\left(T_{o}\right)$, peak temperature $\left(T_{p}\right)$, end temperature $\left(T_{c}\right)$ and gelatinization enthalpy $(\Delta \mathrm{H})$ was calculated and recorded.

\subsection{Statistical analysis}

All experiments were conducted in triplicate. Data reported are averages of three determinations. The significance of differences $(p<0.05)$ was assessed using independent t-test performed by SPSS software version 23.0.

\section{Results and discussion}

\subsection{Proximate analysis}

The proximate composition of the cassava is presented in Table 1. Moisture content showed no significant difference $(p>0.05)$ for both locations. Based on the study conducted by Chandra and Samsher (2013), moisture content of wheat, rice, green gram and potato flour were $13 \%, 11 \%, 8 \%$ and $9 \%$ respectively. This shows that cassava flour has a very low moisture content compared to other types of flour. Low moisture content in cassava flour is desirable since this will be decreasing hydrogen cyanide content as well as improves the palatability of cassava flour produce (Cumbana et al., 2007). Hsu et al. (2003) reported that high-quality flour usually contains moisture content range from $9.0 \%$ to 12.0\%. Apea-Bah et al. (2011) reported that cassava flour sold in the market showed that moisture content was the range from $6.34 \%$ to $14.58 \%$. Moisture is an important parameter in the storage of cassava flour, very high levels greater than $12 \%$ allow for microbial growth and thus low levels are favourable and give relatively longer shelf life. All the samples had good moisture levels and hence have the potential for better shelf life. No significant different $(\mathrm{p}>0.05)$ observed for ash content. However, values recorded were higher compared to results obtained by Rodríguez-Sandoval et al. (2008) in which ash content ranged from $0.1 \%$ to $0.7 \%$. This suggests that cassava grown in Tawau and Semporna contain high in minerals. Niba et al. (2001) reported that the composition of ash in cassava is influenced by mineral content in the soil where the cassava grows.

Table 1. Proximate analysis of cassava flour grown in Tawau and Semporna

\begin{tabular}{lcc}
\hline \multicolumn{1}{c}{ Analysis } & Tawau & Semporna \\
\hline Moisture content (\%) & $6.33 \pm 0.58^{\mathrm{a}}$ & $5.97 \pm 1.16^{\mathrm{a}}$ \\
Ash (\%) & $2.43 \pm 0.30^{\mathrm{a}}$ & $2.19 \pm 0.16^{\mathrm{a}}$ \\
Crude protein (\%) & $2.07 \pm 0.11^{\mathrm{b}}$ & $2.69 \pm 0.02^{\mathrm{a}}$ \\
Crude fat (\%) & $0.55 \pm 0.04^{\mathrm{b}}$ & $0.68 \pm 0.01^{\mathrm{a}}$ \\
Total dietary fibre (\%) & $2.38 \pm 0.16^{\mathrm{a}}$ & $2.09 \pm 0.01^{\mathrm{b}}$ \\
Carbohydrate (\%) & $26.39 \pm 0.80^{\mathrm{a}}$ & $27.02 \pm 1.14^{\mathrm{a}}$ \\
\hline
\end{tabular}

* In a row, numbers followed by different letters differ significantly at $\mathrm{p}<0.05$

Cassava flour planted in Semporna contains high 
protein $(2.69 \%)$ content compared to cassava from Tawau $(2.07 \%)$ and they were significantly different $(p<0.05)$. However, protein content from both locations was high as compared to the value reported by Nuwamanya et al. (2010), Rodríguez-Sandoval et al. (2008) and Ceballos et al. (2008). Buitrago, (1990) reported that protein content of cassava roots in the range of $1-3 \%$ on a dry basis.

Result obtained from the determination of fat content of cassava flour from Tawau and Semporna were $0.55 \%$ and $0.68 \%$ respectively with a significant difference $(p<0.05)$. This value falls within the range based on a study conducted by Moorthy (2002) which is between $0.19 \%$ to $0.98 \%$. Fat content in flour influenced paste texture in which fat favour to obtain a stable viscosity (Moorthy, 2002). However, high-fat content in cassava flour is an undesirable attribute since too much fat will lead to the high possibility for rancidity and increase cloudiness in flour (Mishra and Rai, 2006). Roa et al. (2014) stated that high-fat content is the causes of low swelling power and solubility in flour.

Total dietary fibre of cassava flour planted in Tawau and Semporna was $2.38 \%$ and $2.09 \%$ respectively with significant difference $(p<0.05)$. Result obtained from this study is as expected based on literature review in which study conducted by Fakir et al. (2012) shows that crude fibre in cassava flour falls between the ranges $1.66 \%$ to $4.27 \%$. Carbohydrate content in cassava flour showed no significant difference $(p>0.05)$ for samples obtained from Tawau and Semporna.

\subsection{Functional properties of cassava flour}

The functionality of foods is the properties of food ingredient other than a nutritional attribute, which has a great impact on its application. The functional characteristic determines the utilization and use of food material for various food products. Table 2 shows the results of various functional properties of cassava determined. Bulk density value for both samples (Tawau and Semporna) was $0.57 \mathrm{~g} / \mathrm{cm}^{3}$ and $0.79 \mathrm{~g} / \mathrm{cm}^{3}$, respectively $(p>0.05)$. The values obtained were higher than brown tiger flour (Cyperus esculentus) as reported by Oladele and Aina (2007). Bulk density is a measure of the heaviness of a flour sample. Karuna et al. (1996) and Jones et al. (2000) reported that bulk density is generally affected by the particle size and density of the flour and it is one of the essential parameter in determining the type of packaging material, handling and application in the food industry.

$\mathrm{pH}$ results recorded for $\mathrm{pH}$ of Tawau was higher than for Semporna, 6.75 and 6.72, respectively $(p<0.05)$. Typical $\mathrm{pH}$ of cassava flour falls in the range between
5.5 to 8.5 (Aryee et al., 2006). Apea-Bah et al. (2011) reported that the $\mathrm{pH}$ value of cassava flour obtained in Ghana, ranging between 5.07 and 6.65. Higher $\mathrm{pH}$ value (6.22) was reported for cassava flour analyzed in Tanzania (Muzanila et al., 2000). $\mathrm{pH}$ is one of the important attributes in order to maximize the application of cassava flour in food industries especially in the making of bakery products (Aryee et al., 2006). Since both cassava flour that grows from Tawau and Semporna have a neutral $\mathrm{pH}$ value, it makes the process to apply it into food industry much easier.

Table 2. Functional properties of cassava flour grown in Tawau and Semporna

\begin{tabular}{lcc}
\hline \multicolumn{1}{c}{ Analysis } & Tawau & Semporna \\
\hline Bulk density $\left(\mathrm{g} / \mathrm{cm}^{3}\right)$ & $0.57 \pm 0.05^{\mathrm{b}}$ & $0.79 \pm 0.13^{\mathrm{a}}$ \\
$\mathrm{pH}$ & $6.75 \pm 0.07^{\mathrm{a}}$ & $6.72 \pm 0.11^{\mathrm{b}}$ \\
Water absorption capacity $(\mathrm{mL} / \mathrm{g})$ & $1.12 \pm 0.05^{\mathrm{a}}$ & $1.30 \pm 0.11^{\mathrm{a}}$ \\
Oil absorption capacity $(\mathrm{mL} / \mathrm{g})$ & $1.31 \pm 0.26^{\mathrm{a}}$ & $1.31 \pm 0.17^{\mathrm{a}}$ \\
Foam capacity $(\%)$ & $3.66 \pm 0.58^{\mathrm{b}}$ & $7.33 \pm 3.21^{\mathrm{a}}$ \\
Emulsion capacity $(\%)$ & $10.67 \pm 1.15^{\mathrm{a}}$ & $10.33 \pm 1.52^{\mathrm{a}}$ \\
\hline
\end{tabular}

* In a row, numbers followed by different letters differ significantly at $\mathrm{p}<0.05$

Water and oil absorption capacity results are shown in Table 2. The water absorption capacity was 1.30 and $1.12 \mathrm{~mL} / \mathrm{g}$ for Semporna and Tawau, respectively, indicating that sample from Semporna has higher water absorption capacity. The difference may be attributed to the difference in their carbohydrate contents. Water absorption capacity describes flour-water association ability under limited water supply. Water absorption capacity recorded is in line with past findings where typical water absorption capacity of cassava flour falls between the range of $1.13 \mathrm{~mL} / \mathrm{g}$ to $2.01 \mathrm{~mL} / \mathrm{g}$ (Aryee et al., 2006). Mbougueng et al. (2008) found that water absorption capacity for cassava starch $1.82 \mathrm{~mL} / \mathrm{g}$.

According to Aryee et al. (2006), the water absorption capacity of cassava flour is depending on the power of aggregation between starch molecules. Weak aggregation power between starch molecules causes the surface of its molecular to form a bond with water molecules become easier thus increase the rate of water absorption capacity. Water absorption capacity of flour is an important feature in order to increase its application in ready-to-eat food such as instant noodles and soup (Singh, 2001).

The oil absorption capacity is the flavour retaining capacity of flour which is an important element in food formulations. Oil absorption capacity showed no significant difference $(p>0.05)$ between both samples. Oil absorption capacity is highly related to lipophilic properties of the starch molecule in cassava flour 
(Danbaba et al., 2014). Mbougueng et al. (2008) stated that the variation values show weather in water or oil absorption capacity is depended on the degree of probability of hydroxyl group to form hydrogen and the covalent bond between the starch granule network. Furthermore, water and oil absorption capacity also depend on the intrinsic factors such as the composition of amino acid, protein conformation and surface polarity of protein hydrophobicity (Chandra and Samsher, 2013).

The foaming capacity of cassava flour from Semporna was higher than that of Tawau, $7.33 \%$ and $3.66 \%$, respectively. Kaushal et al. (2012) reported that foaming capacity is related to protein content in cassava flour in which high protein content will increase foaming capacity and vice versa. Data obtained from proximate analysis supporting the idea from Kaushal et al. (2012) where protein content in cassava flour from Semporna is higher comparatively with Tawau in which both with $2.69 \%$ and $2.07 \%$. In a system, the protein that is distributed randomly will lower down the water surface tension lead to the situation in which protein will form a cohesive film that continuous between each other between the airwave and formed foam (Chandra and Shamser, 2013).

No significant difference $(\mathrm{p}>0.05)$ was observed for emulsion capacity between cassava flour from Tawau and Semporna in which both with $10.67 \%$ and $10.33 \%$ respectively. Kaushal et al. (2012) stated that the emulsion capacity of flour is influence by the hydrophobicity of protein. Furthermore, Chandra and Samsher (2013) reported that emulsion capacity is influenced by three main factors which are solubility, $\mathrm{pH}$ value and viscosity. Protein content to increase the formation of the emulsion, as well as stabilized formed emulsion in a system, is very important in order to apply the flour into bakery product such as cake and frozen desert. This is because most all of the bakery product needs an emulsifier to stabilize emulsion during the processing and storage of the final product (Adebowale et al., 2005).

Colour is an important quality attribute of flour which affects the appearance and consumer acceptability of food products. Results of colour analyses are shown in Table 3. Statistical analysis shows that all values $\left(L^{*}, a^{*}\right.$ and $\left.b^{*}\right)$ are significantly different $(\mathrm{p}<0.05)$ between samples from Tawau and Semporna. Flour from Tawau was whiter (94.06) compared to flour from Semporna (92.45), which was slightly more yellowish with $b^{*}$ values of 9.86 and 8.44 , respectively. The colour of flour from Tawau was more intense with $a^{*}$ values of -0.11 as compared to flour from Semporna (0.63). Sun et al. (2006), reported that the difference of colour in flour is due to the composition of the cassava such as ash content, protein, pigment, and starch.

Table 3. $\mathrm{L}^{*}, \mathrm{a}^{*}$ and $\mathrm{b}^{*}$ value of cassava flour grown in Tawau and Semporna

\begin{tabular}{ccc}
\hline Parameter & Tawau & Semporna \\
\hline$L^{*}$ & $94.06 \pm 0.03^{\mathrm{a}}$ & $92.45 \pm 0.06^{\mathrm{b}}$ \\
$a^{*}$ & $-0.11 \pm 0.01^{\mathrm{b}}$ & $0.63 \pm 0.05^{\mathrm{a}}$ \\
$b^{*}$ & $8.44 \pm 0.00^{\mathrm{b}}$ & $9.86 \pm 0.03^{\mathrm{a}}$ \\
\hline
\end{tabular}

* In a row, numbers followed by different letters differ significantly at $\mathrm{p}<0.05$

According to Ayetigbo et al. (2018), cassava flour made from cassava root retains the colour of the root flesh. The reason behind could be that carotenoids are colour-active compounds that are lipid-soluble and the colour retention in flour could be due to the complex with mucilage and latex as well as starch-lipid, fiberlipid, and protein-lipid interactions. Hence, cassava flour retains a more intense colour, while cassava starch made from cassava root is relatively purer in state and has less intense colour.

\subsection{Thermal properties}

Pasting, gelatinization and retrogradation properties are shown in Tables 4, 5 and 6, respectively. Pasting properties of flour is important in order to determine its suitability for application in the food industry. There is a significant difference $(\mathrm{p}<0.05)$ showed between cassava flour from Tawau and Semporna in several parameters of pasting properties such as peak viscosity, trough viscosity and breakdown viscosity were observed. It is also revealed that value for peak viscosity for both samples are higher than the final viscosity. The higher the peak viscosity the higher the swelling index, while low paste viscosity is indicative of higher solubility as a result of starch degradation or dextrinization (Shittu et al., 2001). According to Moorthy (2002), low values of final viscosity compared to peak viscosity indicate that probability of cassava starch contained in the flour to retrograde is low. No significant different $(\mathrm{p}>0.05)$ showed for both sample in terms of final viscosity, setback viscosity, pasting temperature and peak time.

Values obtained from this study are lower than the findings reported by Cameron et al. (2007) on pasting properties of potatoes and rice. Moorthy (2002) stated that cassava flour has a low pasting property compared to other types of flour made from tubers. However, low pasting temperature causes the process of making flourwater solution into a paste is easier compared to flour that has high pasting temperature such as in potatoes and rice. This is due to the stabilization of starch granule towards heat are low causes its molecular structure to be easily interrupted (Cameron et al., 2007). 
Table 4. Pasting properties of cassava flour grown in Tawau and Semporna

\begin{tabular}{lcc}
\hline \multicolumn{1}{c}{ Parameter } & Tawau & Semporna \\
\hline Peak Viscosity (cP) & $2697.67 \pm 885.07^{\mathrm{a}}$ & $3667.00 \pm 125.42^{\mathrm{b}}$ \\
Trough Viscosity (cP) & $1390.00 \pm 218.25^{\mathrm{b}}$ & $1549.00 \pm 51.29^{\mathrm{a}}$ \\
Breakdown Viscosity (cP) & $1550.00 \pm 474.93^{\mathrm{b}}$ & $2072.00 \pm 89.35^{\mathrm{a}}$ \\
Final Viscosity (cP) & $2166.00 \pm 19.00^{\mathrm{a}}$ & $2243.00 \pm 63.00^{\mathrm{a}}$ \\
Setback Viscosity (cP) & $676.00 \pm 27.07^{\mathrm{a}}$ & $654.00 \pm 45.10^{\mathrm{a}}$ \\
Pasting Temperature $\left({ }^{\circ} \mathrm{C}\right)$ & $75.07 \pm 0.05^{\mathrm{a}}$ & $75.13 \pm 0.06^{\mathrm{a}}$ \\
Peak Time (min) & $4.36 \pm 0.08^{\mathrm{a}}$ & $4.40 \pm 0.04^{\mathrm{a}}$ \\
\hline
\end{tabular}

* In a row, numbers followed by different letters differ significantly at $\mathrm{p}<0.05$

Table 5. Gelatinization properties of cassava flour grown in Tawau and Semporna

\begin{tabular}{lcc}
\hline \multicolumn{1}{c}{ Parameter } & Tawau & Semporna \\
\hline Onset $\left({ }^{\circ} \mathrm{C}\right)$ & $70.59 \pm 0.27^{\mathrm{a}}$ & $68.99 \pm 0.05^{\mathrm{b}}$ \\
Peak $\left({ }^{\circ} \mathrm{C}\right)$ & $74.94 \pm 0.06^{\mathrm{a}}$ & $74.06 \pm 0.03^{\mathrm{a}}$ \\
End $\left({ }^{\circ} \mathrm{C}\right)$ & $79.81 \pm 0.44^{\mathrm{b}}$ & $80.03 \pm 0.06^{\mathrm{a}}$ \\
Enthalpy $(\mathrm{J} / \mathrm{g})$ & $2.96 \pm 0.07^{\mathrm{a}}$ & $2.41 \pm 0.02^{\mathrm{a}}$ \\
\hline
\end{tabular}

* In a row, numbers followed by different letters differ significantly at $\mathrm{p}<0.05$

Table 6. Retrogradation properties of cassava flour grown in Tawau and Semporna

\begin{tabular}{lcc}
\hline \multicolumn{1}{c}{ Parameter } & Tawau & Semporna \\
\hline Onset $\left({ }^{\circ} \mathrm{C}\right)$ & $50.17 \pm 0.22^{\mathrm{a}}$ & $50.97 \pm 0.09^{\mathrm{a}}$ \\
Peak $\left({ }^{\circ} \mathrm{C}\right)$ & $56.58 \pm 0.37^{\mathrm{a}}$ & $57.44 \pm 0.23^{\mathrm{a}}$ \\
End $\left({ }^{\circ} \mathrm{C}\right)$ & $63.08 \pm 0.10^{\mathrm{a}}$ & $62.26 \pm 0.34^{\mathrm{a}}$ \\
Enthalpy $(\mathrm{J} / \mathrm{g})$ & $0.21 \pm 0.03^{\mathrm{a}}$ & $0.09 \pm 0.04^{\mathrm{a}}$ \\
\hline
\end{tabular}

* In a row, numbers followed by different letters differ significantly at $\mathrm{p}<0.05$

Onset $\left(T_{o}\right)$, peak $\left(T_{p}\right)$ and end temperature $\left(T_{c}\right)$ as well as enthalpy values $(\Delta \mathrm{H})$ were obtained from DSC measurements. DSC results revealed that sample from Tawau had higher onset and peak temperature as compared to Semporna. Gelatinization temperature of both cassava flours shows a high value compared to study conducted by Sandoval and Fernadez (2013) in which the range of temperature for $\mathrm{T}_{0}, \mathrm{~T}_{\mathrm{p}}$ and $\mathrm{T}_{\mathrm{c}}$ falls between $60.99^{\circ} \mathrm{C}$ to $66.01{ }^{\circ} \mathrm{C}, 66.14^{\circ} \mathrm{C}$ to $71.00^{\circ} \mathrm{C}$ and $69.91{ }^{\circ} \mathrm{C}$ to $77.22^{\circ} \mathrm{C}$ respectively. However, $\Delta \mathrm{H}$ in this study exhibit low value compared to the past study conducted by Sandoval and Fernandez (2013) in which ranged value falls between $7.75 \mathrm{~J} / \mathrm{g}$ to $8.11 \mathrm{~J} / \mathrm{g}$.

Sandoval and Fernandez (2013) stated that the gelatinization parameter of cassava flour is higher compared to cassava starch. This is due to cassava flour contained other components such as protein, fat and fibre that compete for water between each other lead to interruption for gelatinization process. Furthermore, Aryee et al. (2005) reported that cassava that grows at the dry area will have high gelatinization temperature compared to cassava that grows at area high in humidity. Cassava flour has high gelatinization temperature is suitable to be applied in the food industry that used high temperature during processing such as in the canned food industry (Betancur-Ancona et al., 2001).

There were no significant differences for all retrogradation properties of cassava starch planted in both locations. However, $\mathrm{T}_{\mathrm{p}}$ value obtained from this study show higher value with $55.54^{\circ} \mathrm{C}$ and $55.62^{\circ} \mathrm{C}$ compared to study conducted by Raphael et al. (2011) that is ranged from $51.01^{\circ} \mathrm{C}$ until $53.35^{\circ} \mathrm{C}$ whereas enthalpy value in this study is lower with just 0.40 and $0.79 \mathrm{~J} / \mathrm{g}$ compared to study conducted by Raphael et al. (2011) that is ranged from 1.60 to $5.25 \mathrm{~J} / \mathrm{g}$.

\section{Conclusion}

Cassava planted in both location which is Tawau and Semporna eventually have high potential to be applied in the food industry. Several analyses on physicochemical and functional properties of cassava flour and starch show positive results. This study found that different locations influenced proximate compositions of cassava flour, where significant differences were observed for crude protein, crude fat and dietary fibre contents. Besides, significant differences were also observed for bulk density, $\mathrm{pH}$, colour and foaming capacity. Pasting profiles revealed that cassava grown in Semporna showed better properties as compared to cassava from Tawau. This data suggests a weak associative force between starch granules will favour the process of hydrolysis in manufacturing of high glucose syrup.

\section{References}

Adebowale, Y.A., Adeyemi, I.A. and Oshodi, A.A. (2005). Functional and physico-chemical properties of six Mucuna species. African Journal of Biotechnology, 4(12), 1461-1468.

AOAC. (2000). Official Methods of Analysis of AOAC International. $17^{\text {th }}$ ed. USA: AOAC International, Md.

Apea-Bah, F.B., Oduro, I., Ellis, W.O. and SafoKantanka, O. (2011). Factor analysis and age at harvest effect on the quality of flour from four cassava varieties. World Journal of Dairy and Food Sciences, 6(1), 43-54.

Aryee, F.N.A., Oduro, I., Ellis, W.O. and Afuakwa, J.J. (2005). The physicochemical properties of flour samples from the roots of 31 varieties of cassava. Food Control, 17(11), 916-922. https:// doi.org/10.1016/j.foodcont.2005.06.013

Ayetigbo, O., Latif, S., Abass, A. and Joachim, M. 
(2018). Comparing characteristics of root, flour and starch of biofortified yellow-flesh and white-flesh cassava variants, and sustainability considerations: A review. Sustainability, 10(9), 3089. https:// doi.org/10.3390/su10093089

Barratt, N., Chitundu, D., Dover, O., Elsingal, J., Eriksson, S., Guma, L., Haggblade, M., Haggblade, S., Henn, T.O., Locke, F.R., O’Donnell, C., Smith, C. and Stevens, T. (2006). Cassava as drought insurance: Food security implications of cassava trials in Central Zambia. Agrekon, 45(1), 106-123. https://doi.org/10.1080/03031853.2006.9523737

Benesi, I.R.M., Labuschagne, M.T., Herselman, L., Mahungu, N.M. and Saka, J.K. (2007). The effect of genotype, location and season on cassava starch extraction. Euphytica, 160(1), 59-74. https:// doi.org/10.1007/s10681-007-9589-x

Betancur-Ancona, D.A, Chel-Guerrero, L.A., CameloMatos, R.I. and Ortiz-Davila, G. (2001). Physicochemical and functional characterization of baby lima vean (Phaseolus lunatus) starch. Starch/ Starke, 53(5), 219-226. https://doi.org/10.1002/1521379X(200105)53:5<219::AID-STAR219>3.0.CO;2$\mathrm{R}$

Buitrago, A.J.A. (1990). La yucca en la alimentacion animal., p. 450. Cali, Colombia: Centro Internacional de Agricultura Tropical.

Cameron, K., Wang, Y. and Moldenhauer, A. (2007). Comparison of starch physicochemical properties from medium-grain rice cultivars grown in California and Arkansas. Starch/Starke, 59(12), 600608. https://doi.org/10.1002/star.200700662

Ceballos H., Sanchez T., Morante N., Fregene M., Dufour D., Smith A., Denyer K., Perez J., Calle F. and Mestres C. (2006). Discovery of an amylose-free starch mutant in cassava (Manihot esculenta Crantz). Journal of Agriculture and Food Chemistry, 55, 7469-7476. https://doi.org/10.1021/jf070633y

Ceballos, H., Iglesias, C.A., Pérez, J.C. and Dixon, A.G.O. (2004). Cassava breeding: opportunities and challenges. Plant Molecular Biology, 56, 503-515. https://doi.org/10.1007/s11103-004-5010-5

Ceballos, H., Sánchez, T., Denyer, K., Tofi, A.P., Rosero, E.A. and Dufour, D. (2008). Induction and identification of a small-granule, high-amylose mutant in cassava (Manihot esculenta Crantz). Journal of Agricultural and Food Chemistry, 56, 7215-7222. https://doi.org/10.1021/jf800603p

Chandanasree, D., Gul, K. and Riar, C.S. (2016). Effect of hydrocolloids and sry heat modification on physicochemical, thermal, pasting and morphological characteristics of cassava (Manihot esculenta) starch. Food Hydrocolloids, 52, 175-182. https://doi.org/10.1016/j.foodhyd.2015.06.024

Chandra, K.D. and Samsher, A.Y. (2013). Assessment of functional properties of different flours. African Journal of Agricultural Research, 8(38), 4849-4852.

Chávez, A.L., Sánchez, T., Jaramillo, G., Bedoya, J.M., Echeverry, J., Bolaños, E.A., Ceballos, H. and Iglesias C.A. (2005). Variation of quality traits in cassava roots evaluated in landraces and improved clones. Euphytica, 143(1-2), 125-133. https:// doi.org/10.1007/s10681-005-3057-2

Cumbana, A., Mirione, E., Cliff, J. and Bradbury, J.H. (2007). Reduction of cyanide content of cassava flour in Mozambique by the wetting method. Food Chemistry, 101(3), $894 \quad$ - 897. https:// doi.org/10.1016/j.foodchem.2006.02.062

Danbaba, N., Ukwungwu, M.N., Maji, A.T., Ndindeng, S.A., Jiya, A.G., Danfulani, S. and Onyeneke, E.N. (2014). End-use quality of upland Nerica rice (Oryza sativa $\mathrm{L}$ ) as affected by the addition of sweet cassava (Low cyanide, Manihotesculenta) flour. International Journal of Agriculture and Forestry, 4 (3), 237-245.

Enidiok, S.E., Attah, L.E. and Otuechere, C.A. (2008). Evaluation of moisture, total cyanide and fiber contents of garri produced from cassava (Manihot utilissima) varieties obtained from Awassa in Southern Ethiopia. Pakistan Journal of Nutrition, 7 (5), 625-629. https://doi.org/10.3923/ pjn.2008.625.629

Eriksson, E. (2013). Flour from three local varieties of cassava (Manihot esculenta Crantz): physicochemical properties, bread making quality and sensory evaluation. Uppsala: Swedish University of Agricultural Science.

Fakir, M.S.A., Jannat, M., Mostafa, M.G. and Seal, H. (2012). Starch and flour extraction and nutrient composition of tuber in seven cassava accessions. Journal of Bangladesh Agriculture University, 10(2), 217-222. https://doi.org/10.3329/jbau.v10i2.14698

FAO (Food and Agriculture Organization of the United Nations) (2007). FAO Yearbook. Retrieved from FAO website: www.fao.org.

FAOSTAT. (2011). FAOStat: Top Production-World (Total) - 2009. Retrieved from FAO website: http:// faostat.fao.org/.

Grace, M.R. (1977). Cassava processing. Plant production and protection series, No. 3. Rome: FAO

Hsu, C.L., Chen, W., Weng, Y.M. and Tseng, C.Y. (2003). Chemical composition, physical properties, and antioxidant activities of yam flours as affected by different drying methods. Food Chemistry, 83(1), 
85-92. https://doi.org/10.1016/S0308-8146(03)00053 $-0$

Jabatan Pertanian Malaysia. (2019). Perangkaan Tanaman Sayur-Sayuran Dan Tanaman Ladang. Retreived from Department of Agriculture Malaysia website: http://www.doa.gov.my/index/resources/ aktiviti_sumber/sumber_awam/maklumat_pertanian/ perangkaan_tanaman/

perangkaan_sayur_tnmn_ladang_2018.pdf

Kaushal, P., Kumar, V. and Sharma, H.K. (2012). Comparative study of physico-chemical, functional, anti-nutritional and pasting properties of taro (Colocasia esculenta), rice (Oryza sativa), pegion pea (Cajanus cajan) flour and their blends. LWTFood Science and Technology, 48(1), 59-68. https:// doi.org/10.1016/j.lwt.2012.02.028

Mbougueng, P.D., Tenin, D., Scher, J. and Tchiengang, C. (2008). Physichochemical and functional properties of some cultivar of irish potato and cassava starches. Journal of Food Technology, 6(3), 139-146.

Mishra, S. and Rai, T. (2006). Morphology and functional properties of corn, potato and tapioca starches. Food Hydrocolloids, 20(5), 557-566. https://doi.org/10.1016/j.foodhyd.2005.01.001

Montagnac, J.A., Davis, C.R. and Tanumihardjo, S.A. (2009). Nutritional value of cassava for use as a staple food and recent advances for improvement. Comprehensive Reviews in Food Science and Food Safety, 8(3), 181-194. https://doi.org/10.1111/j.1541 $-4337.2009 .00077 . x$

Moorthy, S.N. (2002). Physicochemical and functional properties of tropical tuber starches: A review. Starch/Stärke, 54(12), 559-592. https:// doi.org/10.1002/1521-379X(200212) 54:12<559::AID-STAR2222559>3.0.CO;2-F

Mustapha, S., Mohammed, U.M., Adeosun, N.O., Mathew, T.J., Muhammed, S.S. and Ibn-Aliyu, A. (2015). Nutritional and functional characterization of undecorticated groundnut (Arachis hypogaea L.) seeds from Bosso Market, Minna, Nigeria. American Journal of Food Science and Technology, 3(5), 126131.

Muzanila, Y., Brennan, J. and King, R. (2000). Residual cyanogens, chemical composition and aflatoxins in cassava flour from Tanzanian villages. Food Chemistry, 70(1), 45-49. https://doi.org/10.1016/ S0308-8146(00)00062-5

Niba, L.L., Bokanga, M.M., Jackson, E.L., Schlimme, D.S. and Li, B.W. (2001). Physicochemical properties and starch granular characteristics of flour from various Manihot esculenta (cassava) genotypes.
Journal of Food Science, 67(5), 1707-1705. https:// doi.org/10.1111/j.1365-2621.2002.tb08709.x

Nuwamanya, E., Baguma, Y., Emmambux, N., Taylor, J. and Patrick, R. (2010). Physicochemical and functional characteristics of cassava starch in Ugandan varieties and their progenies. Journal of Plant Breeding and Crop Science, 2(1), 1-11.

Okigbo, B.N. (1980). Nutritional implications of projects giving high priority to the production of staples of low nutritive quality. In the case for cassava (Manihot esculenta, Crantz) in the humid tropics of West Africa. Food Nutrition Bulletin, 2, 1-10. https://doi.org/10.1177/156482658000200404

Oladele, A.K. and Aina, J.O. (2007). Chemical composition and functional properties of flour produced from two varieties of tiger nut (Cyperus esculentus). African Journal of Biotechnology, 6, 2473-2476. https://doi.org/10.5897/AJB2007.0002391

Roa, D.F., Santagapita, P.R., Buera, M.P. and Tolaba, M.P. (2014). Ball milling of amaranth starchenriched fraction. Changes on particle size, starch crystallinity, and functionality as a function of milling energy. Food Bioprocess Technology, 3, 1015. https://doi.org/10.1007/s11947-014-1283-0

Rodríguez-Sandoval, E., Fernández-Quintero, A., Cuvelier, G., Relkin, P. and Bello-Pérez, L. (2008). Starch retrogradation in cassava flour from cooked parenchyma. Starch/Stärke, 60(3-4), 174-180. https://doi.org/10.1002/star.200700683

Salcedo, A., Del Valle, A., Sanchez, B., Ocasio, V., Ortiz, A., Marquez, P. and Siritunga, D. (2010). Comparative evaluation of physiological postharvest root deterioration of cassava (Manihot esculenta) accessions: visual vs. Hydroxy coumarins fluorescent accumulation analysis. African Journal of Agricultural Research, 5, 138-144.

Sandoval, A.A. and Fernández, Q.A. (2013). Physicochemical characterization of two cassava (Manihot esculenta Crantz) starches and flours. Scientia Agroalimentaria, 1, 19-25.

Sanni, L.O., Adebowale, A.A., Maziya-Dixon, B. and Dixon, A.G.O. (2008). Chemical Composition and pasting properties of $\mathrm{cmd}$ resistant cassava clones planted at different locations. Journal of Food Agriculture and Environmental, 6(2), 97-104.

Shittu, T.A., Lasekan, O.O., Sanni, L.O. and Oladosu, M.O. (2001). The effect of drying methods on the functional and sensory characteristics of pukuru-a fermented cassava product. ASSET Series, 1(2), 916.

Singh, U. (2001). Functional properties of grain legume 
flours. Journal of Food Science and Technology, 38 (3), 191-199.

Siritunga, D., Arias-Garzon, D., White, W. and Sayre, R.T. (2004). Over-expression of hydroxynitrile lyase in transgenic cassava roots accelerates cyanogenesis and food detoxification. Plant Biotechnology Journal, 2(1), 37-43. https://doi.org/10.1046/j.14677652.2003.00047.x

Sun, L., Zhou, G., Zhi, G. and Li, Z. (2006). Effect of different milling methods on flour quality and performance in steamed breadmaking. Journal of Cereal Science, 45(1), 18-23. https:// doi.org/10.1016/j.jcs.2006.02.004

Tan, S.L. and Engku Ismail, E.A. (2010). Cassava: getting a new lease on life in Malaysia? presented at Proceeding 8th Regional Workshop, 20-24 Oct. 2008, Vientiane, Laos.

Tewe, O.O and Lutaladio, N. (2004). Cassava for livestock feed in sub-Saharan Africa. Rome, Italy: FAO. 